\section{Amfenac increases the radiosensitivity of uveal melanoma cell lines}

BF Fernandes ${ }^{1}$, J-C Marshall' ${ }^{1}$, S Di Cesare ${ }^{1}$, P Logan', S Maloney' and MN Burnier Jr' ${ }^{1,2}$

\begin{abstract}
Purpose To evaluate the proliferation rates of five human uveal melanoma (UM) cell lines after treatment with amfenac, a cyclooxygenase (COX)-2 inhibitor, and subsequent radiation exposure. Methods Five human UM cell lines (92.1, SP6.5, MKT-BR, OCM-1, and UW-1) and one human fibroblast cell line (BJ) were incubated with amfenac. Treated and non-treated cell lines were then exposed to various doses of $\gamma$ radiation: 0, 2, 4, 6, and $8 \mathrm{~Gy}$. Sulphorhodamine$B$ assay was used to assess proliferation rates $48 \mathrm{~h}$ post-radiation.

Results Treatment of UM cell lines with amfenac prior to radiation led to a marked reduction in proliferation rates. This difference was statistically significant in all cell lines at every radiation dose $(P<0.005)$, with the exception of 92.1 at $2 \mathrm{~Gy}(P=0.157)$. Fibroblasts treated with amfenac showed significantly higher proliferation rates after 2 and $8 \mathrm{~Gy}$, with no significant differences at 0,4 , and $6 \mathrm{~Gy}$. Conclusions The radiosensitivity of UM cell lines was increased by the administration of amfenac, the active metabolite of nepafenac. There appears to be a radioprotective effect of amfenac on human fibroblasts. The topical administration of nepafenac may decrease tumour recurrence and radiation-induced complications while broadening the indications for radiotherapy by treating larger tumours. Eye (2008) 22, 701-706; doi:10.1038/sj.eye.6703042; published online 30 November 2007
\end{abstract}

Keywords: uveal melanoma; radiation; COX-2; amfenac; cell lines

\section{Introduction}

Uveal melanoma (UM) is the most common primary intraocular malignant tumour in adults with an incidence of seven cases per million. ${ }^{1}$ Enucleation of the affected eye was the only available treatment for UM for most of the last century. ${ }^{2}$ However, with the advent of more conservative alternatives to treat the primary tumour, enucleation rates have substantially declined in recent years. The procedure is now reserved for large tumours or those cases where there is no hope of regaining vision. ${ }^{3}$

Radiation is the preferred form of treatment for most cases of UM. ${ }^{4} \mathrm{UMs}$ are typically treated with a calculated apex dose of 70-85 Gy. ${ }^{5}$ Iodine-125 is the most commonly used isotope for plaque radiotherapy of choroidal melanomas, ${ }^{6}$ although cobalt- 60 , ruthenium106, iridium-192, strontium-90, and palladium103 have also been used. ${ }^{3}$ Modern techniques for brachytherapy involve suturing a shielded plaque containing seeds of the radioactive isotope to the sclera. This remains in place for a specified number of days to deliver the proper dose of radiation. Although the rates of tumour control are high, visual acuity is compromised in $25-35 \%$ of cases. ${ }^{6}$ Some of the complications associated with the treatment are neovascular glaucoma, cataract, radiation retinopathy, and optic nerve neuropathy. ${ }^{7}$ Thus, a substantial number of eyes are still enucleated due to failure of tumour control or radiation-related complications.

There are two forms of the cyclooxygenase (COX) enzyme, COX-1 and COX-2. While COX-1 is expressed constitutively in normal tissues, ${ }^{8}$ COX-2 is an inducible enzyme expressed in response to a variety of inflammatory and mitogenic stimuli. ${ }^{9}$ COX-2 expression has been reported in a wide variety of malignant tumours, ${ }^{10-12}$ including uveal melanoma. ${ }^{13}$ The expression of COX-2 has been linked to various processes, including tumour proliferation, ${ }^{14}$ immunosuppression, ${ }^{15}$ and metastasis. ${ }^{16,17}$ Specific COX-2 inhibitors are currently in use for patients diagnosed with familial
${ }^{1}$ Department of

Ophthalmology and Pathology, The McGill University Health Center \& Henry C Witelson Ocular Pathology Laboratory, Montreal, Canada

${ }^{2}$ Department of Ophthalmology. Federal University of São Paulo—UNIFESP/EPM, São Paulo, Brazil

Correspondence: BF Fernandes,

Department of

Ophthalmology and Pathology,

The McGill University Health Center \& Henry C Witelson Ocular Pathology

Laboratory,

3775 University Street,

Room 216,

Montreal, Quebec, Canada H3A-2B4

Tel: + 15143987192 ext. 00384;

Fax: + 15143985728

E-mail: bruno.mtl@

gmail.com

Received: 13 June 2007 Accepted in revised form: 27 October 2007 Published online: 30 November 2007

The authors have no financial conflict of interest regarding this article. 
adenomatous polyposis, a genetic disorder, which predisposes patients to colon cancer. ${ }^{18}$ The effectiveness of these selective inhibitors has been investigated in a variety of tumours and shows promise for use as an adjuvant therapy. ${ }^{19}$

COX-2 inhibitors have also previously been shown to increase the radiosensitivity of lung ${ }^{20}$ and breast ${ }^{21}$ cancer cell lines. Moreover, it has been demonstrated that a COX-2 inhibitor is capable of minimizing radiation damage to non-neoplastic tissues. ${ }^{22}$ Nepafenac is a COX2 inhibitor formulated for topical administration to the eye. ${ }^{23,24}$ The purpose of our study was to determine the effects of amfenac, the active metabolite of nepafenac, on the radiosensitivity of five human UM cell lines and one human fibroblast cell line.

\section{Methods}

\section{Cell culture}

Four previously characterized human UM cell lines (92.1, SP6.5, MKT-BR, OCM-1), one transformed human uveal melanocyte cell line (UW-1) and one human fibroblast cell line (BJ, American Type Culture Collection, USA) were incubated at $37^{\circ} \mathrm{C}$ in a humidified $5 \% \mathrm{CO}_{2}$-enriched atmosphere. ${ }^{25}$ The cell lines used have previously been graded in terms of proliferative and invasive abilities and metastatic potential. ${ }^{25}$ The UM cell lines were cultured in RPMI-1640 medium (Invitrogen, Burlington, ON, Canada), supplemented with 5\% heat inactivated fetal bovine serum (FBS), $1 \%$ fungizone, and $1 \%$ penicillinstreptomycin purchased from Invitrogen (Burlington, ON, Canada). The fibroblast cell line was cultured in DMEM medium (Invitrogen, Burlington, ON, Canada), supplemented with $10 \%$ heat-inactivated FBS, $1 \%$ fungizone, and $1 \%$ penicillin-streptomycin purchased from Invitrogen (Burlington, ON, Canada). Cells were cultured as a monolayer in $25 \mathrm{~cm}^{2}$ flasks (Fisher, Whitby, ON, Canada) and observed two times weekly, at every media change, for normal growth by phase contrast microscopy. The cultures were grown to confluence and passaged by treatment with $0.05 \%$ trypsin in EDTA (Fisher) at $37^{\circ} \mathrm{C}$ and washed in $7 \mathrm{ml}$ RPMI- 1640 media before being centrifuged at $120 \mathrm{~g}$ for $10 \mathrm{~min}$ to form a pellet. Cells were then suspended in $1 \mathrm{ml}$ of medium and counted using the Trypan Blue dye exclusion test for use in all subsequent assays.

The UM cell lines 92.1, SP6.5, and MKT-BR were established by Dr Jager (University Hospital Leiden, The Netherlands), Dr Pelletier (Laval University, Quebec, Canada) and Dr Belkhou (CJF INSERM, France), respectively. Dr Albert (University of WisconsinMadison, USA) established the OCM-1 and UW- 1 cell lines. ${ }^{26,27}$

\section{Irradiation}

Prior to radiation, each cell line was seeded at a concentration of 500000 cells per $\mathrm{ml}$ in micro petri dishes and incubated overnight with a $150 \mathrm{nM}$ concentration of amfenac (Alcon Laboratories Inc., Fort Worth, TX, USA), the active metabolite of nepafenac. The concentration of $150 \mathrm{~nm}$ was the recommended $50 \%$ inhibitory concentration $\left(\mathrm{IC}_{50}\right)$ of COX-2 activity. ${ }^{28}$ On the following day, the cells were exposed to graded doses of $\gamma$ irradiation: 2, 4, 6, and $8 \mathrm{~Gy}\left({ }^{137} \mathrm{Cs}\right.$ source, $\gamma$ Cell 1000). Controls consisted of cell lines exposed to radiation without prior incubation with amfenac.

Post radiation, all micro petri dishes containing 500000 cells / plate were trypsinized using $0.05 \%$ Trypsin in EDTA, then washed in 5\% FBS RPMI solution, and centrifuged for $5 \mathrm{~min}$ at $3000 \mathrm{~g}$. The cells were then diluted to a concentration of 50000 cells $/ \mathrm{ml}$ in $5 \%$ FBS RPMI solution. These dilutions were seeded in a 96-well plate format at a concentration of 5000 cells per well and left to incubate at $37^{\circ} \mathrm{C}$ for $48 \mathrm{~h}$ to adhere to the bottom of the wells. After $48 \mathrm{~h}$, we could already see colonies formed. Thus, to guarantee exponential growth, we chose to run the proliferation assay at this time point. The proliferation assay was done in triplicate per exposure condition.

\section{Sulphorhodamine-B assay}

The Sulphorhodamine-B assay kit (TOX-6, Sigma-Aldrich Co., St Louis, Missouri, USA) was used to measure total cell material as described previously. ${ }^{29}$ Each of the treated and non-treated cell lines were seeded into wells at a concentration of $5 \times 10^{3}$ cells per well, with a minimum of three wells per cell line/radiation dose. The cells were then allowed to incubate for $48 \mathrm{~h}$ at $37^{\circ} \mathrm{C}$. Following the incubation period, the cells were fixed to the bottom of the wells using a solution of $50 \%$ Trichloroacetic acid for $1 \mathrm{~h}$ at $4^{\circ} \mathrm{C}$. The plates were then rinsed with distilled water, to remove trichloroacetic acid and medium, and later air dried. The Sulphorhodamine$B$ dye solution was next added to each well and allowed to stain for $25 \mathrm{~min}$. The Sulphorhodamine-B solution was subsequently removed by washing with a $10 \%$ acetic acid solution and once more allowed to air dry. The dye that had become incorporated into the fixed cells at the bottom of the wells was solubilized in a $10 \mathrm{mM}$ solution of Tris. The absorbance of the solute was measured using a microplate reader at a wavelength of $510 \mathrm{~nm}$.

\section{Data analysis}

The Student's $t$-test was used to compare proliferation results between treated and non-treated cell lines after 
various doses of radiation. A value of $P<0.05$ was considered statistically significant.

\section{Results}

The results of the Sulphorhodamine-B proliferation assay for each cell line are presented in Figure 1. The actual values, SD, and $P$-values are shown in Table 1 . The effect of radiation was significantly more pronounced in the UM cell lines treated with amfenac. The difference in the proliferation rates between treated and non-treated cell lines was statistically significant in all cell lines at all radiation doses $(P<0.05)$, except for the 92.1 cell line exposed to $2 \mathrm{~Gy}(P=0.157)$.

The effect of amfenac on different doses of radiation is seen in Figure 2. The proliferation rates of the treated cell lines are represented as a percentage of the untreated controls. A positive value means that the proliferation rate was higher after the addition of the drug, thus suggesting a radioprotective effect. In contrast, a negative value means that the cell line proliferated less when the compound was added, indicating that the effects of radiation were enhanced. The effect of amfenac on the radiosensitivity of all UM cell lines was more pronounced with increasing doses of radiation. The synergism between amfenac and radiation was more pronounced in the MKT-BR, OCM-1, SP6.5, and UW-1 cell lines than in the 92.1 cell line.

A human fibroblast cell line was used to test the effect of amfenac on the radiosensitivity of a non-neoplastic cell type. The results of the Sulphorhodamine-B proliferation assay did not show a statistically significant difference for radiation doses of 4 and $6 \mathrm{~Gy}$. Amfenac demonstrated a radioprotective effect, in terms of statistically significant higher proliferation rates, in the treated fibroblasts after 2 and $8 \mathrm{~Gy}$ of radiation.

\section{Discussion}

There is increasing evidence that COX-2 inhibitors may work as radiosensitizing agents. ${ }^{30}$ Systemic COX-2 inhibitors are being used in clinical trials for lung cancer and the results are promising. ${ }^{20,31}$ To the best of our knowledge, this is the first time that a drug has been shown to increase the radiosensitivity of UM cell lines. Furthermore, we demonstrated that no such synergistic effect was seen in a non-neoplastic human fibroblast cell line, that was, on the contrary, protected by the addition of amfenac. The finding that the fibroblasts were actually protected from the radiation damage provides in vitro support to the findings of Liang et al. ${ }^{22}$ The authors observed that mice treated with a COX-2 inhibitor showed less damage to the surrounding tissues than the control animals, after receiving $50 \mathrm{~Gy}$ of radiation. Although it was proposed that the protective mechanism would involve the reduction of cytokines and chemokines, our in vitro results show that there is an intrinsic effect not related to tissue inflammation or other host-related factors.
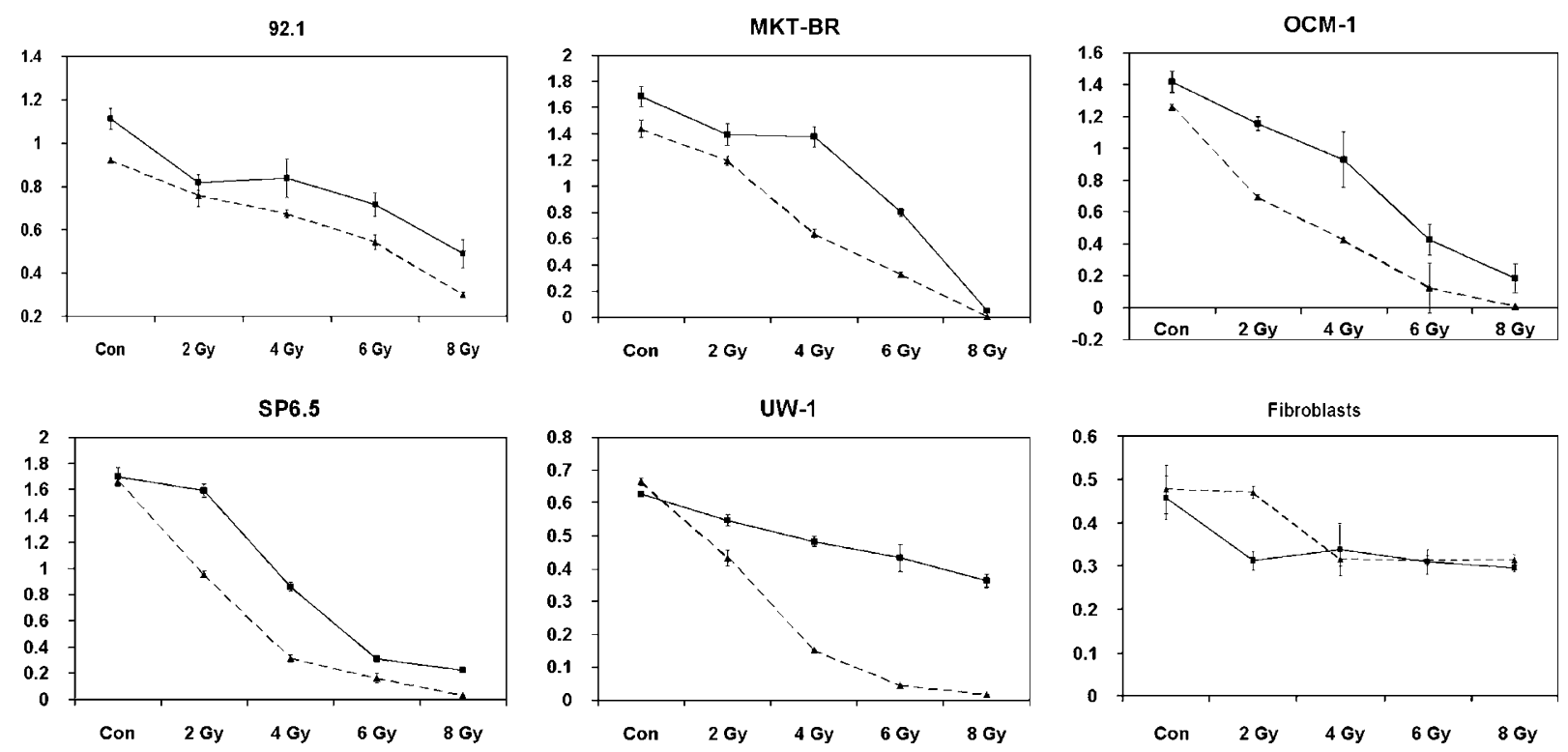

Figure 1 Graphical representation of the effect of amfenac and radiation on cell lines. The absorbance level detected by the Sulphorhodamine-B proliferation assay is seen on the $y$ axis, while the doses of radiation are shown on the $x$ axis. The solid and dashed lines correspond to the non-treated and treated cell lines, respectively. A significant reduction on the proliferation rates was seen only in the uveal melanoma cell lines. 
Table 1 Proliferation rates of five uveal melanoma and fibroblast cell lines after radiation measured by the Sulphorhodamine-B assay kit

\begin{tabular}{|c|c|c|c|}
\hline $\begin{array}{l}\text { Radiation } \\
\text { dose }(G y)\end{array}$ & $\begin{array}{l}\text { Without Amfenac } \\
\text { (absorbance }+S D)\end{array}$ & $\begin{array}{c}\text { With Amfenac } \\
\text { (absorbance }+S D)\end{array}$ & P-value \\
\hline \multicolumn{4}{|l|}{92.1} \\
\hline 0 & $1.11 \pm 0.08$ & $0.92 \pm 0.01$ & 0.002 \\
\hline 2 & $0.82 \pm 0.04$ & $0.76 \pm 0.05$ & 0.157 \\
\hline 4 & $0.84 \pm 0.09$ & $0.67 \pm 0.02$ & 0.036 \\
\hline 6 & $0.72 \pm 0.05$ & $0.54 \pm 0.03$ & 0.009 \\
\hline 8 & $0.49 \pm 0.07$ & $0.3 \pm 0.01$ & 0.007 \\
\hline \multicolumn{4}{|l|}{$M K T-B R$} \\
\hline 0 & 1.69 & 1.44 & 0.013 \\
\hline 2 & 1.39 & 1.19 & 0.017 \\
\hline 4 & 1.38 & 0.63 & $<0.001$ \\
\hline 6 & 0.8 & 0.33 & $<0.001$ \\
\hline 8 & 0.05 & 0.005 & $<0.001$ \\
\hline \multicolumn{4}{|l|}{ OCM-1 } \\
\hline 0 & 1.42 & 1.26 & 0.017 \\
\hline 2 & 1.15 & 0.69 & $<0.001$ \\
\hline 4 & 0.93 & 0.43 & 0.007 \\
\hline 6 & 0.42 & 0.12 & 0.047 \\
\hline 8 & 0.18 & 0.009 & 0.029 \\
\hline \multicolumn{4}{|l|}{ SP6.5 } \\
\hline 0 & 1.7 & 1.66 & 0.42 \\
\hline 2 & 1.59 & 0.95 & $<0.001$ \\
\hline 4 & 0.86 & 0.31 & $<0.001$ \\
\hline 6 & 0.3 & 0.16 & 0.003 \\
\hline 8 & 0.22 & 0.03 & $<0.001$ \\
\hline \multicolumn{4}{|l|}{$U W-1$} \\
\hline 0 & 0.63 & 0.66 & 0.01 \\
\hline 2 & 0.55 & 0.43 & 0.003 \\
\hline 4 & 0.48 & 0.15 & $<0.001$ \\
\hline 6 & 0.43 & 0.04 & $<0.001$ \\
\hline 8 & 0.36 & 0.02 & $<0.001$ \\
\hline \multicolumn{4}{|c|}{ Fibroblast (BJ) } \\
\hline 0 & 0.46 & 0.48 & 0.555 \\
\hline 2 & 0.31 & 0.47 & $<0.001$ \\
\hline 4 & 0.34 & 0.32 & 0.411 \\
\hline 6 & 0.31 & 0.31 & 0.825 \\
\hline 8 & 0.29 & 0.31 & 0.014 \\
\hline
\end{tabular}

$\mathrm{UM}$ is known to be a radioresistant tumour. In vitro studies have shown that downstream defects in the p53 pathway may be involved in resistance to apoptosis, even though the radioresistance of UM is unlikely to be attributed to a single genetic defect. ${ }^{32} \mathrm{UM}$ cell lines show a wide range of radiosensitivity, which may be explained by varied induction of apoptosis, and cell cycle disruption. ${ }^{33}$ The mechanism underlying the synergistic effect of COX-2 inhibitors and radiation remains elusive. One of the proposed mechanisms is the accumulation of cells in the $\mathrm{G}_{2} \mathrm{~S} / \mathrm{M}$ phase of the cell cycle, which is most sensitive to ionizing radiation. ${ }^{34}$ Aside from the intrinsic effect of COX-2 inhibition in cancer cells, the antiangiogenic properties of COX-2 inhibitors may further facilitate induction of apoptosis in vivo and hinder tumour growth. ${ }^{21}$

Nepafenac has a unique prodrug structure and exhibits superior ocular bioavailability properties compared to diclofenac, another NSAID available for topical administration. Nepafenac is an inactive form that requires intraocular bioactivation to become the effective prostaglandin $\mathrm{H}$ synthase inhibitor, amfenac. ${ }^{35}$ Little hydrolytic conversion of nepafenac is seen during transit. Following penetration, nepafenac diffuses through the anterior and posterior chambers of the eye and is accumulated and bioactivated in vascularized tissues: iris, ciliary body, retina, and choroid. ${ }^{36}$ The end result is a prolonged suppression of COX activity, which is a distinct advantage over an NSAID with a free carboxylic acid function. Nepafenac was the only topical anti-inflammatory medication shown to inhibit the blood-retinal barrier breakdown in an animal model of ocular inflammation. ${ }^{24}$ Thus, it is believed that nepafenac is the only topical NSAID to reach therapeutic levels in the posterior segment of the eye. Concentration of the drug achieves its highest peaks in ocular tissues $30 \mathrm{~min}$ after topical administration. ${ }^{24}$

Complications secondary to treatment by plaque radiotherapy occur in up to $70 \%$ of patients, especially when treating larger tumours. ${ }^{7}$ Radiotherapy does not affect only the neoplastic tissue in the eye.

Histopathological studies show increased necrosis, inflammation, fibrosis, and tumour blood vessel damage in irradiated eyes. ${ }^{37}$ The combination of COX-2 inhibitors and radiation is a promising emerging therapy since COX-2 inhibition can selectively enhance the radiosensitivity of a tumour while allowing nonneoplastic tissues to be spared. ${ }^{30}$ The concept that an eyedrop, without significant side effects, ${ }^{38}$ can deliver the drug to an intraocular UM is even more appealing since the systemic complications related to COX-2 inhibition can be circumvented. ${ }^{20}$

In light of our preliminary results, we would encourage the use of nepafenac as an adjunct to radiotherapy in the treatment of UM. However, further studies are needed to characterize the exact mechanism behind the observed synergism. Animal studies would also be valuable before the institution of clinical trials in humans.

In summary, we showed that the radiosensitivity of UM cell lines could be increased by the administration of amfenac, the active metabolite of a commercially available anti-inflammatory topical eye medication. The administration of such a drug to uveal melanoma patients, before radiotherapy, may increase success rates regarding local tumour treatment and control. 


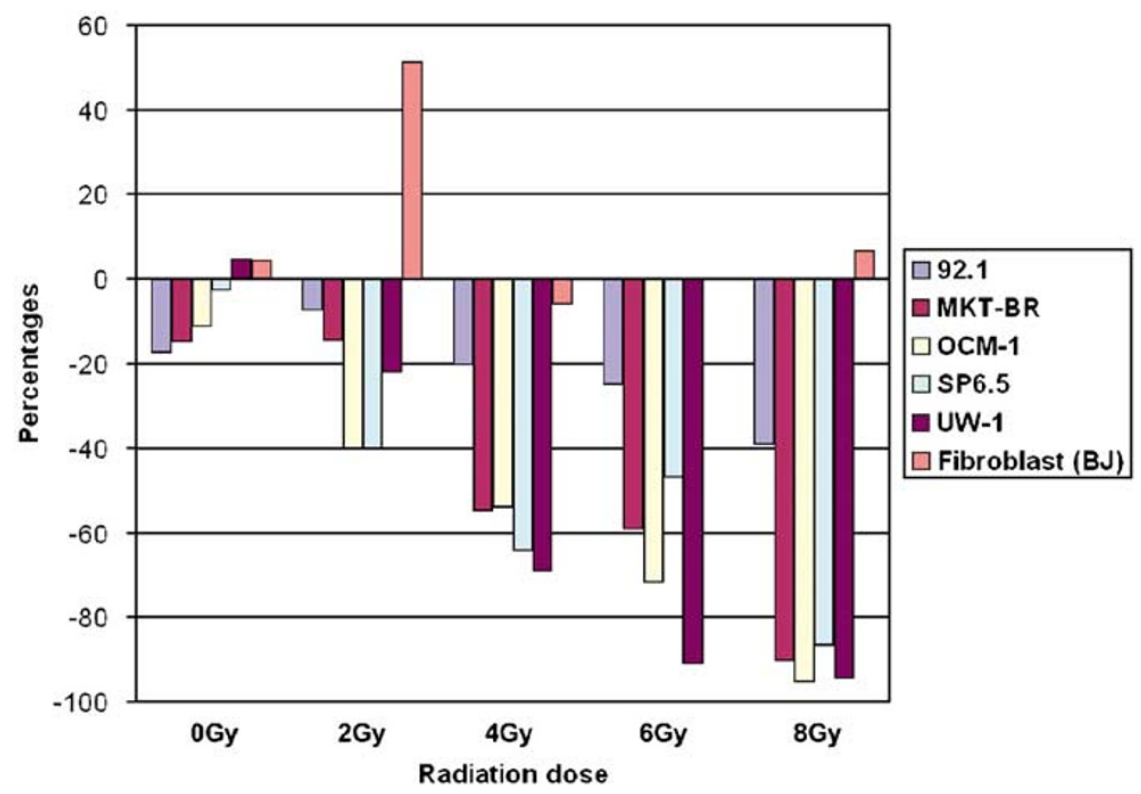

Figure 2 The proliferation rates of the treated cell lines are represented as a percentage of the untreated controls. A positive value reflects a radioprotective effect of amfenac, whereas negative values were a sign of increased radiosensitivity.

\section{Acknowledgements}

Part of this work was presented as a poster at ARVO 2007.

\section{References}

1 Egan KM, Seddon JM, Glynn RJ, Gragoudas ES, Albert DM. Epidemiologic aspects of uveal melanoma. Surv Ophthalmol 1988; 32(4): 239-251.

2 The Collaborative Ocular Melanoma Study Group. The collaborative ocular melanoma study (COMS) randomized trial of pre-enucleation radiation of large choroidal melanoma I: characteristics of patients enrolled and not enrolled. COMS report no. 9. Am J Ophthalmol 1998; 125(6): 767-778.

3 Bell DJ, Wilson MW. Choroidal melanoma: natural history and management options. Cancer Control 2004; 11(5): 296-303.

4 Zhao DY, Shields CL, Shields JA, Gunduz K. Update on the management of posterior uveal melanoma. J Ophthalmic Nurs Technol 1998; 17(2): 66-71.

5 Nath R, Anderson LL, Luxton G, Weaver KA, Williamson JF Meigooni AS. Dosimetry of interstitial brachytherapy sources: recommendations of the AAPM radiation therapy committee task group no. 43. American association of physicists in medicine. Med Phys 1995; 22(2): 209-234.

6 Shields CL, Shields JA, Cater J, Gunduz K, Miyamoto C, Micaily B et al. Plaque radiotherapy for uveal melanoma: long-term visual outcome in 1106 consecutive patients. Arch Ophthalmol 2000; 118(9): 1219-1228.

7 Puusaari I, Heikkonen J, Kivela T. Ocular complications after iodine brachytherapy for large uveal melanomas. Ophthalmology 2004; 111(9): 1768-1777.
8 Smith WL, DeWitt DL, Garavito RM. Cyclooxygenases: structural, cellular, and molecular biology. Annu Rev Biochem 2000; 69: 145-182.

9 Patel MI, Subbaramaiah K, Du B, Chang M, Yang P, Newman RA et al. Celecoxib inhibits prostate cancer growth: evidence of a cyclooxygenase-2-independent mechanism. Clin Cancer Res 2005; 11(5): 1999-2007.

10 Tang TC, Poon RT, Lau CP, Xie D, Fan ST. Tumor cyclooxygenase-2 levels correlate with tumor invasiveness in human hepatocellular carcinoma. World J Gastroenterol 2005; 11(13): 1896-1902.

11 Dai Y, Zhang X, Peng Y, Wang Z. The expression of cyclooxygenase-2, VEGF and PGs in CIN and cervical carcinoma. Gynecol Oncol 2005; 97(1): 96-103.

12 Soumaoro LT, Uetake H, Higuchi T, Takagi Y, Enomoto M, Sugihara K. Cyclooxygenase-2 expression: a significant prognostic indicator for patients with colorectal cancer. Clin Cancer Res 2004; 10(24): 8465-8471.

13 Figueiredo A, Caissie L, Callejo SA, McLean IW, Gold P, Burnier Jr MN. Cyclooxygenase-2 expression in uveal melanoma: novel classification of mixed-cell-type tumours. Can J Ophthalmol 2003; 38(5): 352-356.

14 Williams CS, Sheng H, Brockman JA, Armandla R, Shao J, Washington MK et al. A cyclooxygenase-2 inhibitor (SC58125) blocks growth of established human colon cancer xenografts. Neoplasia 2001; 3(5): 428-436.

15 Kojima M, Morisaki T, Uchiyama A, Doi F, Mibu R, Katano $\mathrm{M}$ et al. Association of enhanced cyclooxygenase-2 expression with possible local immunosuppression in human colorectal carcinomas. Ann Surg Oncol 2001; 8(5): 458-465.

16 Yao M, Zhou W, Sangha S, Albert A, Chang AJ, Liu TC et al. Effects of nonselective cyclooxygenase inhibition with lowdose ibuprofen on tumor growth, angiogenesis, metastasis, and survival in a mouse model of colorectal cancer. Clin Cancer Res 2005; 11(4): 1618-1628.

17 Evans DM, Sloan Stakleff KD. Control of pulmonary metastases of rat mammary cancer by inhibition of UPA and 
COX-2, singly and in combination. Clin Exp Metastasis 2004 21(4): 339-346.

18 Steinbach G, Lynch PM, Phillips RK, Wallace MH, Hawk E, Gordon GB et al. The effect of celecoxib, a cyclooxygenase-2 inhibitor, in familial adenomatous polyposis. $N$ Engl J Med 2000; 342(26): 1946-1952.

19 Arun B, Goss P. The role of COX-2 inhibition in breast cancer treatment and prevention. Semin Oncol 2004; 31(2 Suppl 7): 22-29.

20 Liao Z, Komaki R, Milas L, Yuan C, Kies M, Chang JY et al. A phase I clinical trial of thoracic radiotherapy and concurrent celecoxib for patients with unfavorable performance status inoperable/unresectable non-small cell lung cancer. Clin Cancer Res 2005; 11(9): 3342-3348.

21 Liu W, Chen Y, Wang W, Keng P, Finkelstein J, Hu D et al. Combination of radiation and celebrex (celecoxib) reduce mammary and lung tumor growth. Am J Clin Oncol 2003; 26(4): S103-S109.

22 Liang L, Hu D, Liu W, Williams JP, Okunieff P, Ding I et al. Celecoxib reduces skin damage after radiation: selective reduction of chemokine and receptor mRNA expression in irradiated skin but not in irradiated mammary tumor. Am J Clin Oncol 2003; 26(4): S114-S121.

23 Takahashi K, Saishin Y, Mori K, Ando A, Yamamoto S, Oshima $\mathrm{Y}$ et al. Topical nepafenac inhibits ocular neovascularization. Invest Ophthalmol Vis Sci 2003; 44(1): 409-415.

24 Kapin MA, Yanni JM, Brady MX, McDonough TJ, Flanagan JG, Rawji MH et al. Inflammation-mediated retinal edema in the rabbit is inhibited by topical nepafenac. Inflammation 2003; 27(5): 281-291.

25 Marshall JC, Caissie AL, Callejo SA, Antecka E, Burnier Jr MN. Cell proliferation profile of five human uveal melanoma cell lines of different metastatic potential Pathobiology 2004; 71(5): 241-245.

26 De Waard-Siebinga I, Blom DJ, Griffioen M, Schrier PI, Hoogendoorn E, Beverstock G et al. Establishment and characterization of an uveal-melanoma cell line. Int J Cancer 1995; 62(2): 155-161.

27 Diebold Y, Blanco G, Saornil MA, Fernandez N, Lazaro MC. Morphologic and immunocytochemical characterization of four human uveal cell lines (melanoma- and melanocytesderived). Curr Eye Res 1997; 16(5): 487-495.
28 Gamache DA, Graff G, Brady MT, Spellman JM, Yanni JM Nepafenac, a unique nonsteroidal prodrug with potential utility in the treatment of trauma-induced ocular inflammation: I. Assessment of anti-inflammatory efficacy. Inflammation 2000; 24(4): 357-370.

29 Skehan P, Storeng R, Scudiero D, Monks A, McMahon J, Vistica $\mathrm{D}$ et al. New colorimetric cytotoxicity assay for anticancer-drug screening. J Natl Cancer Inst 1990; 82(13): 1107-1112.

30 Davis TW, Hunter N, Trifan OC, Milas L, Masferrer JL. COX-2 inhibitors as radiosensitizing agents for cancer therapy. Am J Clin Oncol 2003; 26(4): S58-S61.

31 Grimes KR, Warren GW, Fang F, Xu Y, St Clair WH et al. Cyclooxygenase-2 inhibitor, nimesulide, improves radiation treatment against non-small cell lung cancer both in vitro and in vivo. Oncol Rep 2006; 16(4): 771-776.

32 Sun Y, Tran BN, Worley LA, Delston RB, Harbour JW. Functional analysis of the p53 pathway in response to ionizing radiation in uveal melanoma. Invest Ophthalmol Vis Sci 2005; 46(5): 1561-1564.

33 van den Aardweg GJ, Naus NC, Verhoeven AC, de Klein A, Luyten GP. Cellular radiosensitivity of primary and metastatic human uveal melanoma cell lines. Invest Ophthalmol Vis Sci 2002; 43(8): 2561-2565.

34 Furuta Y, Hunter N, Barkley Jr T, Hall E, Milas L. Increase in radioresponse of murine tumors by treatment with indomethacin. Cancer Res 1988; 48(11): 3008-3013.

35 Ke TL, Graff G, Spellman JM, Yanni JM. Nepafenac, a unique nonsteroidal prodrug with potential utility in the treatment of trauma-induced ocular inflammation: II. In vitro bioactivation and permeation of external ocular barriers. Inflammation 2000; 24(4): 371-384.

36 Lane SS. Nepafenac: a unique nonsteroidal prodrug. Int Ophthalmol Clin 2006; 46(4): 13-20.

37 Saornil MA, Fisher MR, Campbell RJ, Robertson DM, Earle JD, Eagle Jr RC et al. Histopathologic study of eyes after iodine I 125 episcleral plaque irradiation for uveal melanoma. Arch Ophthalmol 1997; 115(11): 1395-1400.

38 Lane SS, Modi SS, Lehmann RP, Holland EJ. Nepafenac ophthalmic suspension $0.1 \%$ for the prevention and treatment of ocular inflammation associated with cataract surgery. J Cataract Refract Surg 2007; 33(1): 53-58. 